\title{
Trans- Atlantic Slave Trade and Its Impacts for Modern African
}

\author{
Misgana Yifiru Ayenew \\ Lecturer at Ambo University, Ethiopia
}

\begin{abstract}
Africa experienced two major crisis in its history; slave trade and colonialism. At a time of both events Africa was integrated into global market in unequal and exploitative ways. But, slave trade in general and transAtlantic slave trade in particular lasts for long time and holds the lion share in underdevelopment of Africa. As such, this paper analysis the long term effect of trans-Atlantic slave trade for modern African political economy. To do so, the work employs qualitative research methods and secondary source of data.Before trans-Atlantic slave trade, African peoples were egalitarian, have their own values and civilizations. They were self sufficient and autonomous and there was no huge gap between Africa and Europe. However, Trans -Atlantic slave trade lead to intensification of the gap between Africa and Europe as result of its exploitative nature and deterioration of African values and norms. Hence, large numbers of African were shipped crossing Atlantic Ocean and works on large scale plantation in the new world and these numbers reaches its climax at $18^{\text {th }} \mathrm{c}$. Trans-Atlantic slave trade brought untold causalities on African political economy at time of its occurrence and even at modern time. Thereby, limitation of African economy to monoculture, perverted institution, and creation of fertile ground for colonialism because of weak and fragmented states, decline in population, disturbing family and reducing fertility rates were the major short term impacts of trans-Atlantic slave trade. Moreover, Trans- Atlantic slave trade also serves as important variable to analysis the modern political economy of Africa because of its long term effect.Accordingly, trans-Atlantic slave trade discourages state formation and this in turn obstructs creation of modern economy, laws and public goods. The current absolutist and patrimonial state existing in Africa also trace their origin to the era of trans-Atlantic slave trade. Trans-Atlantic slave trade also responsible for ethnic stratification existing in Africa today as result of mistrust and break down of social bond between peoples so that it lays the basis for intensification of ethnic conflict in modern Africa. Furthermore, it serves as pre-colonial source of modern corruption and modern racism from which Africa is still suffering.Therefore, lingering problems in modern African political economy embedded within trans-Atlantic slave trade so that it plays crucial role for current underdevelopment of the continent.
\end{abstract}

DOI: $10.7176 / \mathrm{IAGS} / 92-01$

Publication date: December $31^{\text {st }} 2021$

\section{Introduction}

Now days, Africa is one of the poorest continent in the world. Hence, this poor condition of the continent is embedded in historical phenomena that the continent faces at different times in which slave trade is one among others. At a time of slave trade, Africa was integrated to global economy on unequal and exploitative bases. Thus, slave trade has a lion share for current underdevelopment of African continent (Acemolgu and Ribson, 2010:21) Slave trade is universal phenomena and not unique to Africa. In addition to Africa; Europe, India, American and others were both victims and beneficiaries of slave trade even though there was variation between them both in degrees and year of practices. According to Zhang (2016:3) Africa experienced slave trade for five centuries and this extends from $14^{\text {th }} \mathrm{c}$ to $19^{\text {th }} \mathrm{c}$. However, this does not mean there was no slave trade prior to $14^{\text {th }} \mathrm{c}$. According to Acemolgu and Ribson (2010:28) slave trade was not stranger to Africans and there had been considerable trading of African slaves by Islamic Arab merchant in North Africa since the year of 1000 before the emergence of Trans- Atlantic slave. Hence, slave trade was dominated by Arab merchants both in and outside Africa before the involvement of Europeans. Before and Within the above time span, Africa experienced a total of four slaves trade and this includes;-Trans-Sahara slave trade, Red sea slave trade, Indian Ocean slave trade and TransAtlantic slave trade. In Red Sea slave trade, slaves were taken from inland of the Red Sea and shipped to Middle East; in Indian ocean slave trade, slaves were taken from Eastern Africa and shipped to either to middle East and India or to plantation in the island of Indian ocean whereas during Transatlantic slave trade, slaves were shipped from West Africa, West central Africa and East Africa to European colonies in the new world (Nunn, 2008:141). Trans-Atlantic slave trade which is the focus area of this paper is the youngest and resulted in enduring effect on African political economy as compared to others while greatly benefiting the Europeans. As such, it formed parts of triangular trade that integrate Africa, America and European continent together. According to Hardy (2014:1) in triangular trade, Europeans exported manufactured goods to Africa and exchanged them for slaves, who were then taken to America, where they were used to produce sugar, molasses, cotton, tobacco, indigo and other goods, which were brought back to Europe. 


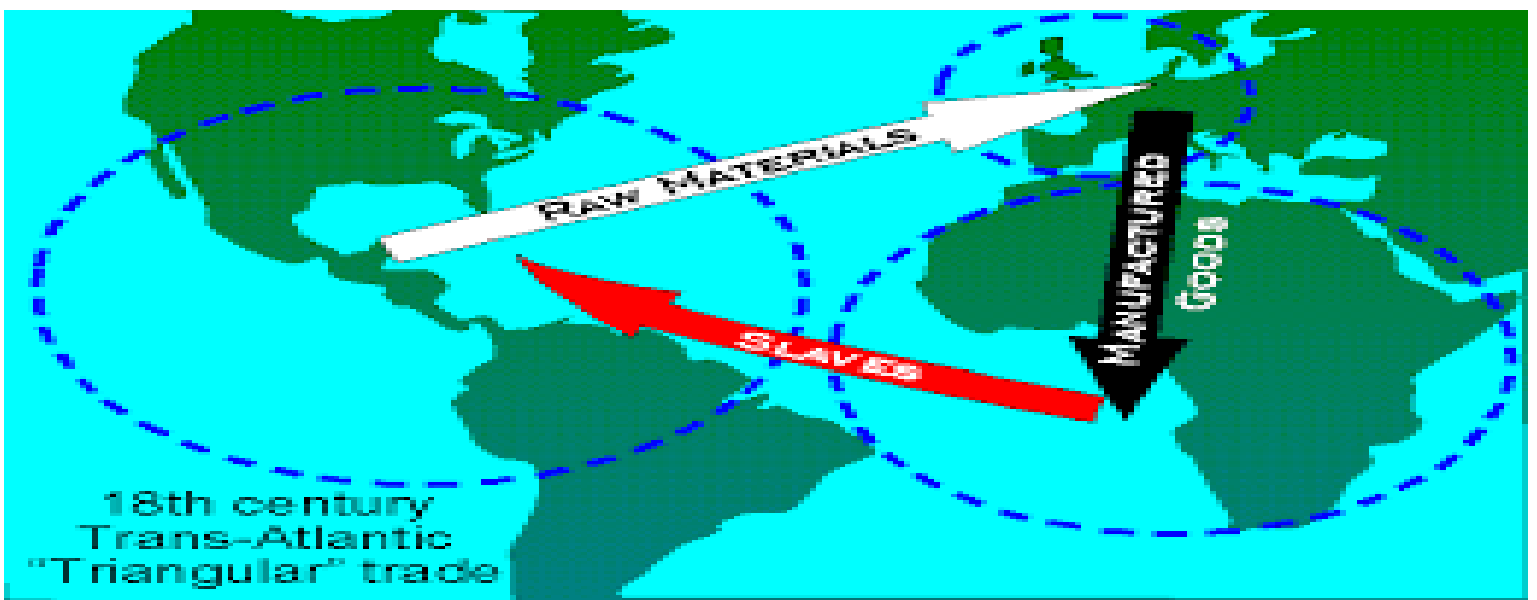

Picture 1: Triangular Trade

Thus, for M'Baye (2006:607) Trans- Atlantic slave trade held back African prospect to prosperous and affects its social and political stability while benefiting Europeans to larger extent and it lays the foundation for economic exploitation and social and political fragmentation which later institutionalized through colonialism and neo colonialism. More or less it creates fertile ground for colonialism by creating weak and fragmented states within Africa and so that Europeans easily penetrate the continent and extend their imperialism.

However, the destructive effects of slave trade in general and Trans-Atlantic slave trade in particular did not restricted to its time of occurrence and has long term effect on current African political economy. According to Nunn (2008:144) slave trade is an important factor that explains Africa's current political economy. Hence, current African political and economic condition has casual relation and deep rooted within past histories of the continent like in slave trade and colonialism.

Hence, this paper aimed to examine Trans-Atlantic slave trade in general and its impacts for modern African political economy in particular. To do so, the work employs qualitative research approach and depends on secondary source of data. Thus, important work of different scholars, books, articles and journals available related to slave trade in general and Trans-Atlantic slave trade in particular are consulted and integrated in a well manner as much as possible.

Accordingly, this paper has six sections. The first section deals with introduction and the second highlights historical evolution of Trans -Atlantic slave trade. On the other hand, the third section examines causes of TransAtlantic slave trade whereas the fourth section deals with its unique features. Similarly, the fifth section elaborate the impacts of Trans-Atlantic slave trade for modern African political economy and the final section ends by providing brief conclusion of the paper.

\section{Historical evolution of Trans- Atlantic Slave trade}

Trans-Atlantic slave trade was one of the largest slave trade that hit and shock Africa for almost five centuries. According to M'Baye (2006:8) Trans-Atlantic slave trade started in 1442 initially as small commercial system based on exchange of African material or human capital such as gold or slaves with few European materials such as guns and silks. These commercial activities were dominated by Portuguese and Spanish until the arrival of other European countries. Accordingly, at the end of $16^{\text {th }} \mathrm{c}$ it evolved to large market that promotes inhumane capture and transportation of Africans to the new world crossing Atlantic Ocean. Consequently, Europeans arrived and established slave trade port in western African coast and continuously exploited African human resource, labor and commodities until it was abolished (ibid).

According to Achebe et al (2018:2-3), Trans- Atlantic slave trade evolved through times and so that has different phases starting from its inception to its abolition. The first phase lasts from 1442-1492. At this time, slave trade was dominated by Portuguese and slaves were transported from Senegambia to Portugal only. The second phase covers the time from 1492-1575. This period was characterized by Spanish arrival in the new world and quite low enslavement of person since Europeans were interested to gold rather than slaves. But, from 1575-1640 the volume of slave trade was increased especially from Angola. According to the authors, the year from 1640-1675 was very important and marks the emergency of English, Dutch and French and their competition with Portuguese and Spanish. More or less slave trade was consolidated from 1675-1700. However, it reaches its point of climax during $18^{\text {th }} \mathrm{c}(1700-1807)$ because of enslavement of large number of Africans to Europe and to the new world.

In 1807 Britain parliament passed an act to abolish slave trade even though Denmark had been the first European nations to do this in 1792 ( ibid,2018:3). However, according to Mlambo (2018:9) there is no unanimous agreement within scholars related to the rationality behind slave trade abolishment initiation by 
Britain and debates are still lingering. Hence, some historians describes the abolition of the slave trade and slavery as complementary with economic trends, while others as a moral or political act that flew in the face of economic interests. But, end of the Atlantic slave trade was not marks the end of slavery itself as it continued in North Africa, Middle East, and the Indian Ocean up to the 1900s, and persisted in sub-Saharan Africa during colonialism even though colonial state came to Africa with the motive of abolishing slave trade (Acemolgu and Ribson,2010:31)

Trans Atlantic slave trade represents the darkest history of African societies as large numbers of Africans were displaced to the new world and engaged in building America and the prosperity of European Christian state. According to M'Bokolo (1998:1) around 11-20 million African slaves were transported across Atlantic Ocean to the new world to work on plantation principally sugar, tobacco, coffee and cotton. But, there is no unanimous agreement within scholar related to numbers of slaves shipped to the new world and consequently some scholars raise the number while others shrinks it.

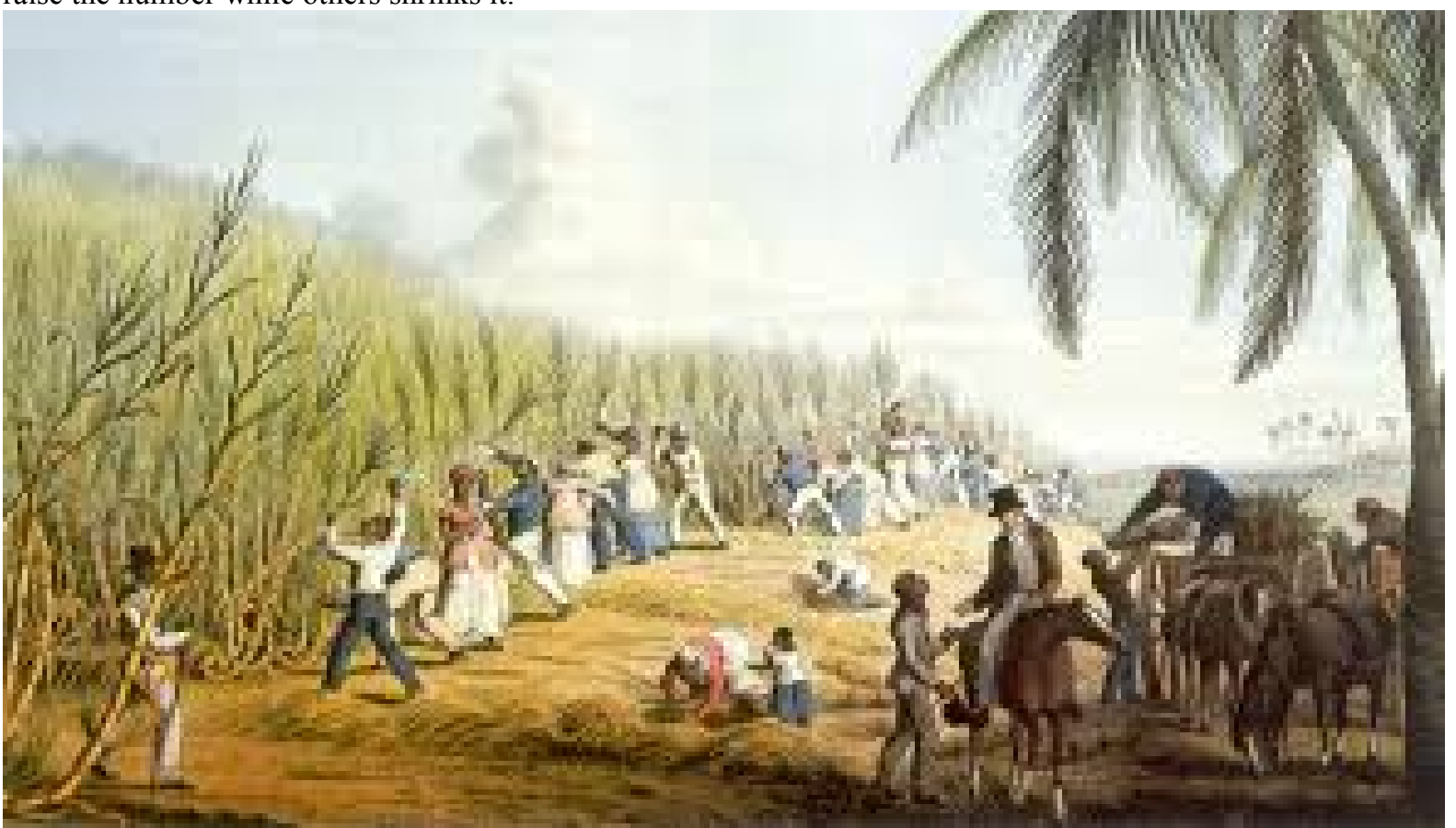

Picture 2: Slave and Sugar in the new world

Hence, slaves were transported mainly from West and West central African countries like Senegambia, Guinea-Bissaau, Guinea and Sierra Leone to America crossing Atlantic Ocean (Achebe et al, 2018:3) so that it effects lives of millions of African peoples even though regional variation exists.

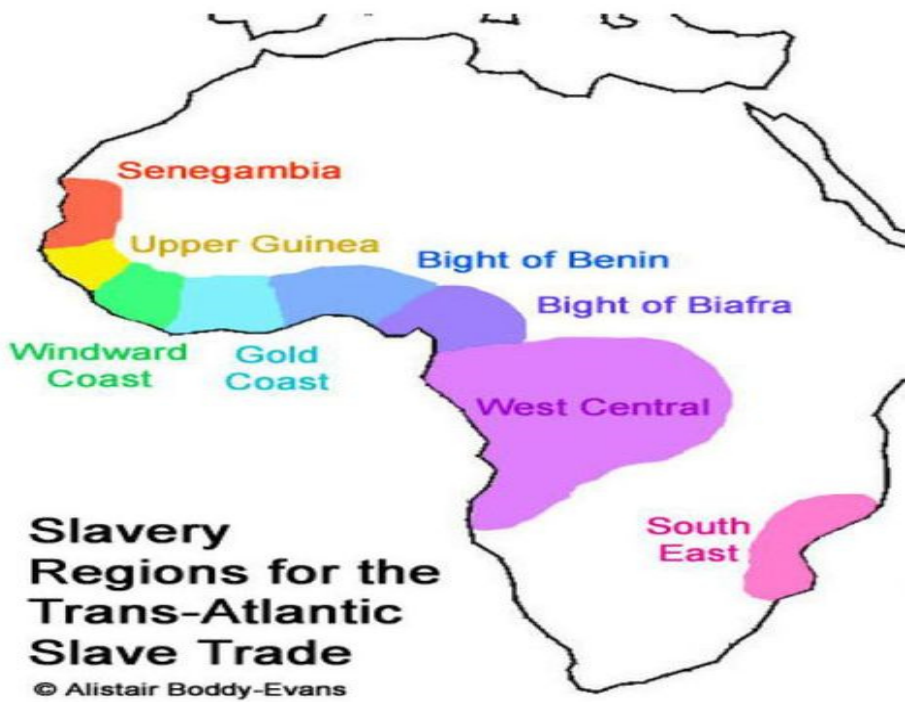

Picture 3: Most Slave trade affected African Regions 


\section{Causes of Trans-Atlantic Slave Trade}

As it has been mentioned before, Trans-Atlantic slave trade started at the mid of $15^{\text {th }} \mathrm{c}$. Hence, $15^{\text {th }} \mathrm{c}$ marks an important centuries in the world history as result of the discovery of American continent in 1492 and foundation of new colonies for Europeans. Consequently, this creates and increase demand for cheap labor for growing economies of the European colonial powers in which Trans-Atlantic slave trade was perceived as an important alternative sources. Because at this time, paid labors were very expensive and indigenous peoples had largely wiped out by diseases and conflicts (Mlambo, 2018:8).

According to Achebe et al (2018:3) Trans-Atlantic slave trade was intensified and emerges as an arena of competition between European states after $16^{\text {th }} \mathrm{c}$. Especially, in $18^{\text {th }} \mathrm{c}$ Britain was the foremost slave-trading power, alongside the French, the Dutch, the Portuguese, and the Spanish, all of whom had colonies in the New World and from $16^{\text {th }} \mathrm{c}-18^{\text {th }} \mathrm{c}$ relatively twelve million Africans were transported across the Atlantic to Brazil, the Caribbean, and North America mainly from West Africa (Hardy, 2014:1).

Europeans were not directly involved in capturing and enslavement of Africa people rather powerful states and African merchants were highly involved in enslavement of their people. Consequently, powerful states were raised in Africa with the main objective of enslaving and raiding African societies especially in West Africa (Acemolgu and Ribson, 2010:30). However, in a certain countries like Angola, Mozambique and Guinea Europeans were directly involved in African Warfare to capture slaves with the help of local blacks (M'Bokolo, 1998:5).

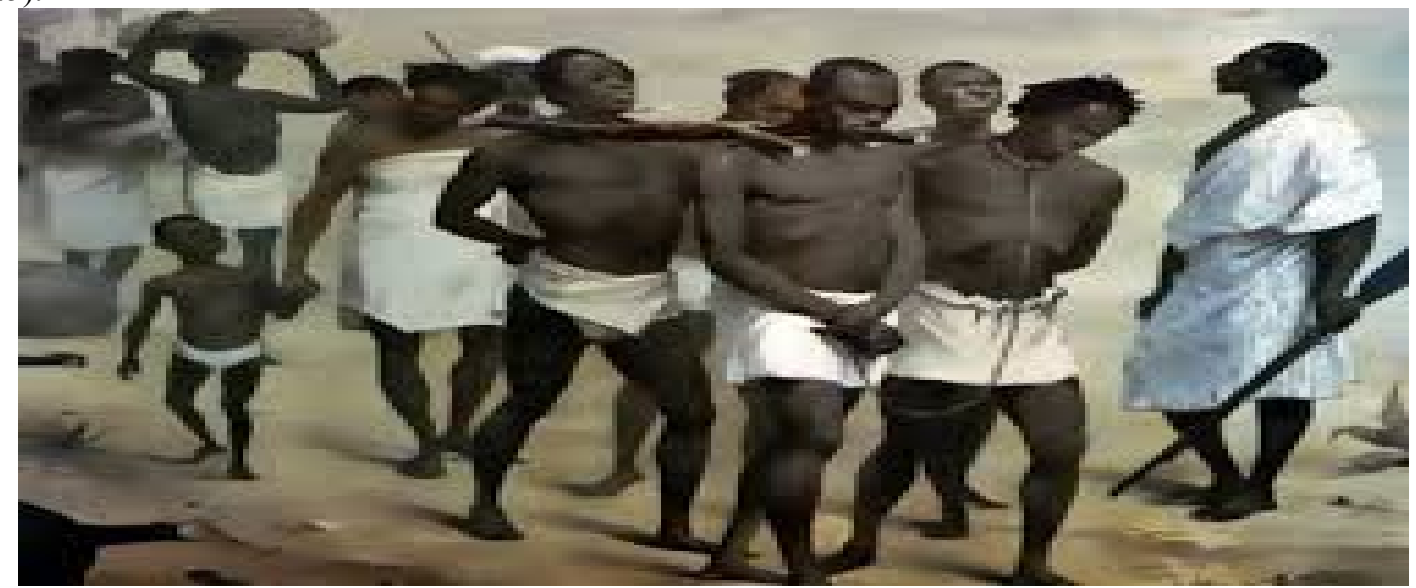

Picture 4: Inhuman capture of African slaves

\section{Unique features of Trans-Atlantic slave trade}

As it has been mentioned before, there are four types of slave trade in Africa in which Trans- Atlantic slave trade is one among others. As compared to others, Trans -Atlantic slave trade was the youngest and has different unique features that make it different from the others. According to Acemolgu and Ribson (2010:29) TranAtlantic slave constituted to the largest number of people enslavement as compared to others and its volume also increases over a time. For instance, in $16^{\text {th }} \mathrm{c}$ about 300,000 slaves were traded across Atlantic Ocean. At this time, number of slave traded a cross Trans -Sahara constitute 550,000. But, number of slaves across Atlantic Ocean increases to $1,350,000$ in $17^{\text {th }} \mathrm{c}$ and $6,000,000$ in $18^{\text {th }} \mathrm{c}$ whereas Trans-Sahara slave trade only constitute 700,000 at the same time. Hence, with the increase of number of slaves involved losses of live also tremendously increases and surpass the earlier. 


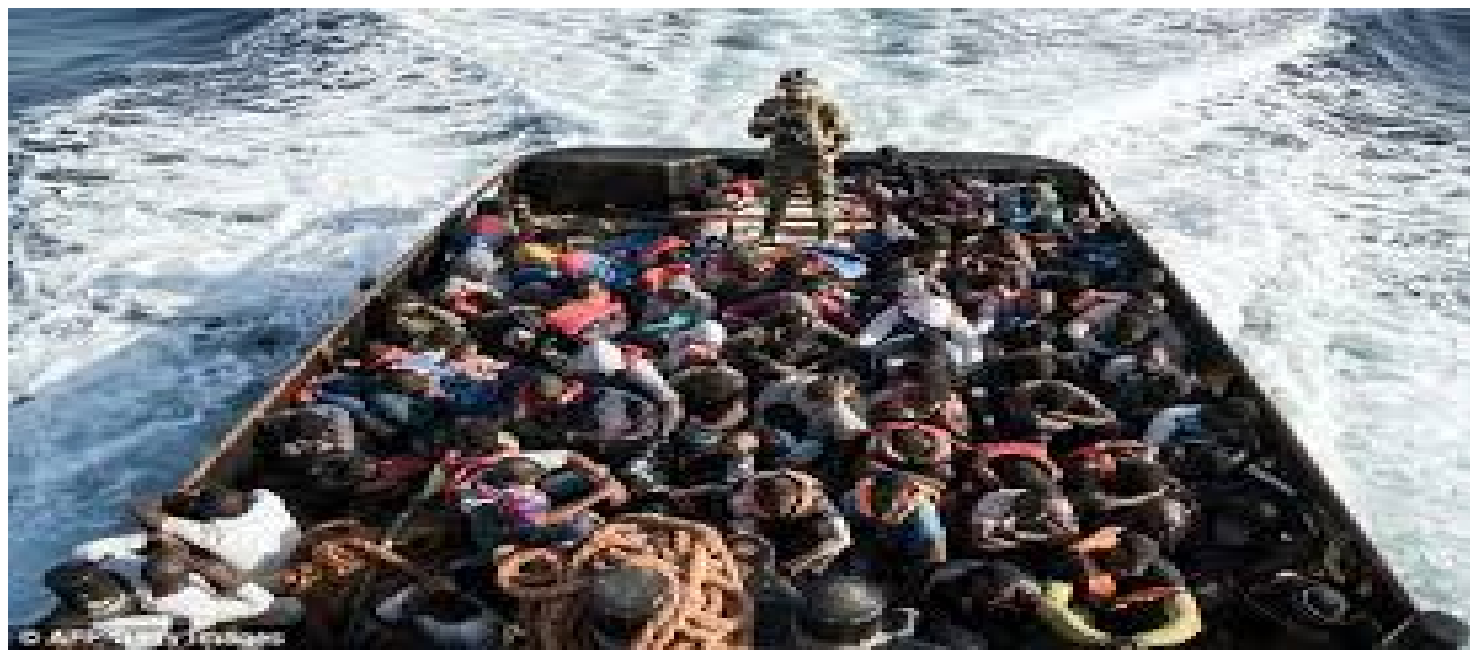

Picture 5: Shipment of Slave trade across Atlantic Ocean

According to Angles (2012:3) at earlier time, slaves were war captives. This means slave was not the main motives for starting an armed conflict. However, unlike the earlier time, with the starting of Trans -Atlantic slave trade, wars were increasingly fought with the sole motives of obtaining slaves. Hence, Strong states with sole motive of slave trading like Asante in Ghana, Oyo state in Nigeria and Dahomey in Benin were emerged in Africa. For these states, slave production and slave trading become the most important economic activities and consequently slave raiding and kidnapping was undertaken forcefully by using fire arms and gun powder exchanged by slave from Europeans. Thus, introduction of guns and bullets from Europe increases and intensifies warfare within the continent and this lead to loss of life of millions of African peoples (Acemolgu and Ribson, 2010:29).

Moreover, Trans-Atlantic slave trade differs from the other in terms of origin of slaves and buyers of slaves. According to Angle (2012:4) in Trans- Atlantic slave trade, both origins and buyers of slave become homogenous. At earlier time, source of slave was both within and outside Africa and slave buyers were both Europeans and non Europeans. However, in trans-Atlantic slave trade, Africa remains the only suppliers of slave while Europeans were the only buyers of slave. As such, Trans-Atlantic slave trade directed at Africans only whereas the Muslim countries enslaved both blacks and whites peoples (M'Bokolo, 1998:1).

Another important feature of Trans-Atlantic slave trade is that unlike the previous ones, individual of the same or similar ethnicities enslaved one another (Nunn, 2008:142). Hence, with the emergence of Trans-Atlantic slave trade, small scale warfare was rampant because of desire to gain power through capturing slave so that people started to consume their own ethnicities, tribes and family members. Thereby, it leads to social and ethnic fragmentation, political instability, weakening state and corruption of judicial institutions. In order to avoid slavery, tribes and clans created alliance with powerful families and kingdoms and this brought constant shifting of ethnic allegiance and enhances mistrust (Benton and Dionne, 2015:226).

Trans-Atlantic slave trade also founded on unique and rigid concepts of bondage. Unlike the earlier type of slave trade, in Trans -Atlantic slave trade conversion to the religion of the master or marriage with the master did not prevent a person or his/her descendents from inheriting the status of slave (M'Baye,2006:608).

\section{Impacts of Trans- Atlantic Slave Trade for Modern African Political Economy}

African continent was affected by dual historical phenomenon and these were slave trade and colonialism. Africa remains under the yolk of slave trade for more than five centuries even though colonialism has short span of time (Nunn, 2008:139). Thus, the current political economy of the continent is embedded within these events as both of them are responsible for current status of Africa in global political economy.

Africa is blessed with natural resource but remain number one poor in the world (Ankilo, 2018:679). Within scholars there is consensus that colonialism and slave trade contributed to Africa's underdevelopment. Because of their exploitative nature, they immensely influence economic, political and social condition of African population. However, according to Njomen (2015:2) slave trade undermines African development than colonialism. Here, the impacts of slave trade can be studied from the angle of short term and long term effect. According to M'Baye(2006:607) slave trade limits African economy to monoculture which was human being at a time of its occurrence. By doing so, it halted the transformation of Africa's mercantilist economy into capitalist economy. Furthermore, slave trade also leads to loss of productive force and effects live of millions of Africans. It bred conflict, mistrust, and decline in population density, fragmentation (ibid), creates weak states and enabling condition for colonialism, disrupted family and marriage structure and reduces fertility. Most importantly, it perverted institutions and increases lawlessness as slavery was used for punishment of all kinds of 
criminals (Acemolgu and Ribson, 2010:30).

But, the economic and political impacts of Trans -Atlantic slave trade was not restricted to short term impact as it influences modern political economy of the continent. According to Nunn (2008:619) current African social, political and economic problems of the continent were rooted in legacy of slave trade as it has many repercussions today and thus these consequences are discussed as follows:-

First and for most, period of Trans- Atlantic slave trade overlapped with state formation in Africa and thus responsible for delay of the process of state formation because of its depopulation and fragmentation implication which has casual relation with current economic development of the continent. According to Acemolgu and Ribson (2010:24) state formation was late in Africa as compared to other parts of the world and this discourages creation of modern economy, public goods and laws within the continent. Hence, this confirms Nunn's (2006:8) view of countries history of state formation as important determinant of current economic performance. Going beyond this, Nunn concluded that, African countries that had centralized pre- colonial state institutions provide more public goods such as education, health and infrastructures and this indicates that, legacy of slave trade has far reaching effect on current African states economic performance.

The consequence of Trans-Atlantic slave trade did not only hinder state formation but also lead to creation of absolutist and patrimonial state in Africa. According to Whatley (2012:1), "slave trade contributed to increase of absolutism and reduction of democracy and liberalism in pre- colonial West Africa." Hence, these absolutists states were consolidated and institutionalized by colonialism and neo colonialism and remain common in most African countries today. In such type of state, rulers exercise power for the purpose of accumulating private wealth; economic institutions were designed to serve the interest of the authoritarian government and access to private property like land was limited and this in turn lead to insecurity of property and instability that blocks further economic development (Acemolgu and Ribson, 2010:27-28).

Slave trade also holds the lion share for the present existing ethnic fractionalization in African continent. According to Benton and Dionne(2015:226) slave trade generate culture of mistrust because of the way slaves were captured by other African which is brutal and supported by military weapons that is exchanged for slaves by Europeans. At this time, slaves were taken through villages or states raiding one another including their relatives and consequently turned the existing relation between villages hostile and breaks social bond up on which trust was built(weaken ties between villages) and hence this impeded the formation of larger communities and broaden ethnic stratification (Nunn, 2008:142). In line with this statement Whatley (2012:5) also argue that, slave trade was responsible for the increases of ethnic fragmentation in Africa that persists today. Thus, slave trade was an important factor in explaining Africa's high level of ethnic fractionalization today.

In connection to increasing ethnic stratification, mistrust created as legacy of slave trade also has far reaching consequences related to current African political economies. According to Benton and Dionne (2015:226) slave trade shapes the recent attitude of citizens toward their trust or distrust in others including their government. Hence, there was negative correlation between trust and slave trade and so that individuals whose ancestor exposed to slave trade in the past were less trusted to others today. According to these scholars, West Africa was one of the most slave trade affected regions. As such, for them, legacy of slave trade takes the lion share for the outbreak of Ebola in 2014 in the region and the delay of responses from home government and international community because of its implication of mistrust.

Another impact of slave trade for modern African political economy is intensifications of conflict. According to Zhang (2016:3) slave trade causes the spatial distribution of conflict in Africa and as result countries that have more slaves exported during slave trade are more prone to conflict today. As it has been mentioned before, slaves were captured through war, raids and kidnapping even within the same ethnicities. Similarly, villages also raided other villages and this created mistrust among individuals, hostile relation and ethnic fractionalization which leads to protracted civil war that existed in Africa today. However, effect of slave trade has regional variation so that high in one region and trivial in other region (ibid).

According to Benton and Dionne (2015:227) civil war in West Africa was deep rooted in the legacy of Trans- Atlantic slave trade. Hereby, West Africa was one of the most slave trade affected region in Africa as compared to other regions because of Europeans arrival in West African coast and their establishment of slave trade ports. Hence, the region was characterized by long civil strife around 1990s and 2000s and continues marginalization and exploitation in global economy because of the impacts of slave trade.

In complement to this, Annan (2014:8) argues that, the root of conflict in West Africa is embedded in interplay of historical factors, social and economic crisis and legacy of authoritarianism. As such, peoples within the regions are hinged on ethnic fragmentation as a result of legacy of slave trade and this intensifies civil strife within the region. Thus, West African countries experienced the burden of conflict at different times. For instance, because of civil strife, tens of thousands were killed and millions of peoples were migrated in Liberia and Sierra Leone. Provision of health and education also retarded as result of the destruction of health institutions. More or less, countries like Mali, Nigeria, Mauritania and C'oted'ivoire are also influenced by insurgency and coup d'état at different times (ibid: 12). Thereby, legacy of slave trade is responsible for current 
internal conflict, insecurity and political instability of African states.

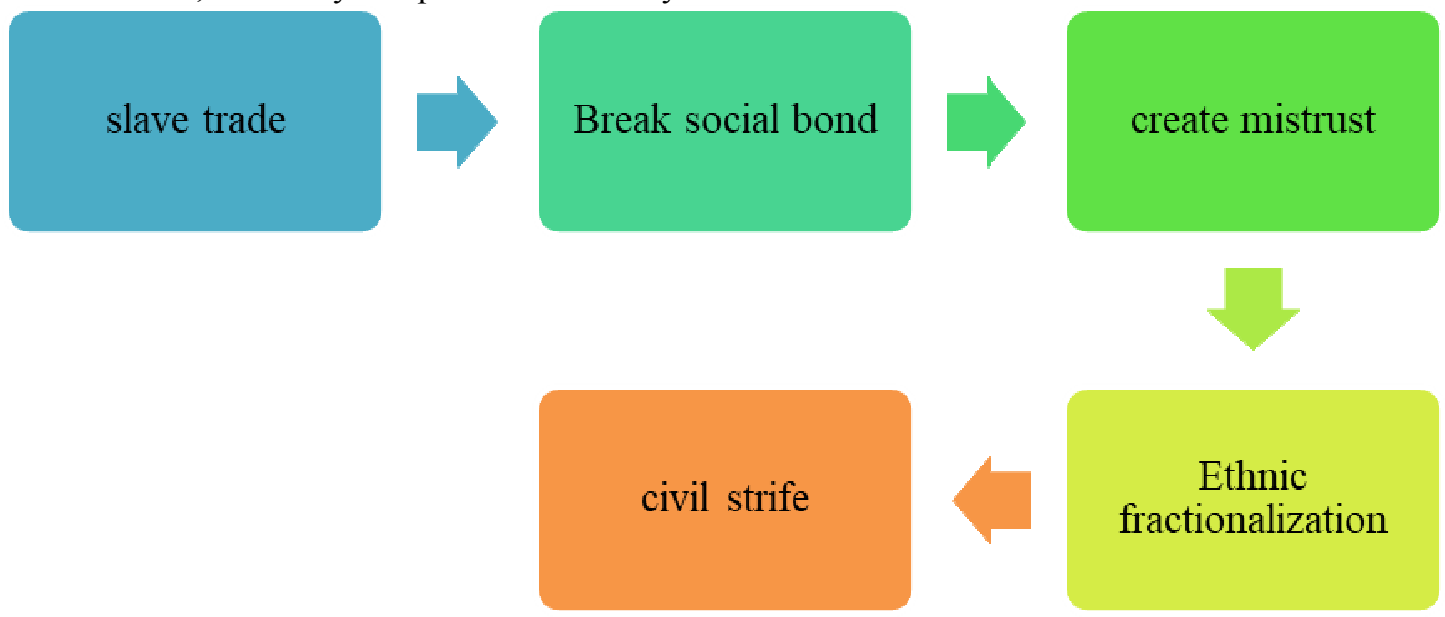

\section{Picture 6: Relationship between slave trade and current conflict in Africa}

Moreover, Trans-Atlantic slave trade also perceived as one source of pre-colonial origins of modern corruption (Nunn, 2008:139). Accordingly, slavery was corruption and it involves theft, bribery and exercise of brute force. According to Njomen $(2015: 2)$ before the emergency of Europeans, bribery and corruption was less practiced in Africa as communities were guided by traditional values and norms. Laws were made collectively and disputes were resolved by head of communities with deliverance of equal justice to all. But, this civilization and cultures were deteriorated with the arrival of Europeans and Middle East with high demand for slave and this gives foundation for modern corruption as they provide military for local kings so as to accelerate the defeat of another kind and capture of slave trade to boost their trade interest. Thus, modern from of corruption like embezzlement of state funds, centralization of state power, little accountability of government officials to the general public, poor infrastructure development and corrupt recruitment process of civil servants in Africa rooted in legacy of slave trade (Njomen, 2015:2).

Finally, according to M'Bokolo(1998:1) Trans Atlantic slave trade engendered the racism and hatred from which Africans still suffering. Because ideology of racism that set up to justify the enslavement of Africa is still seen as aspects of modern racism. Thus, even though slave trade is universal, trans-Atlantic directed to Africans and this lays the foundation for modern racism

\section{Conclusion}

Slave trade has very long history in African continent as it lasts for almost five centuries. At its beginning it was a kind of small commercial activities between European and Africans based on exchange of raw materials with human capital. However, this was evolved through time and reaches its climax at a time of Trans-Atlantic slave trade. Hence, trans Atlantic slave trade was the youngest slave trade and started because of the demand for cheap labor force by Europeans to work on their colonies of New world. As such, Trans Atlantic slave trade formed the part of triangular trade which integrates Africa, European and American continent together in global economy. Thus, large number of African were captured in inhumane way and transported across Atlantic Ocean to the new world.

Trans- Atlantic slave trade was different from Indian Ocean, Trans Saharan and Red sea slave trade in many ways. As compared to others, it was the youngest and has high magnitude and intensity because of large numbers of people enslavement. Hence, waging war with the motive of capturing slave was also started at this time. On the other hand, unlike the others, in Trans-Atlantic slave trade selling and buying of slave was dominated by Africans and European only. Because of its lucrative nature, enslavement of one's own ethnicities also started during this period.

Trans- Atlantic slave trade brings untold causalities on African political economies. As such, its adverse effect is studied from short time and long term angle. At a time of its occurrence, slave trade resulted in decline of population, loss of productive force, mistrust and instabilities, distorted institutional development and creates absolutist and patrimonial state, distributed family and reduce fertility rate. However, the crisis of slave trade is not limited to its short time effect as it has long run effects on current political economy of Africa.

Accordingly, slave trade in general and Trans-Atlantic slave trade in particular delays state formation and even creates absolutist and patrimonial states which were institutionalized by colonialism and neo colonialism. Hence, the delay of state formation obstructs the development of modern economy and politics in Africa and lead to insecure property right. Thereby, Most African states which are now absolutist were tracing their origin to the era of slave trade. Trans-Atlantic slave trade also creates the current existing ethnic fractionalization as result of mistrust generated from brutal nature of slave trade. Moreover, this ethnic fractionalization and mistrust 
lead to protracted civil war in areas of Slave trade affected region especially in West Africa. Furthermore, slave trade also lays the foundation for current intensification of corruption and engendered modern racism

Therefore, Trans- Atlantic slave trade was important variable to explain current African political economy. As such, current economic and social problems such as ethnic fractionalization, instability, absolutism, and corruption that affect the contemporarily African political economy have their roots in Trans- Atlantic slave trade. Hence, Africa was economically self sufficient

and socially stable before the coming of Europeans to trade with them. But, slave trade deteriorated their traditional civilization, values, norms, process of socio-economic development and social peace. Consequently, Africa remains one of the poorest continents because of the legacy of slave trade today.

\section{References}

Acemoglu, Daren and James A. Robinson ( 2010). 'Why Africa is Poor?' Economic History Of Developing Regions. Vol.25. No. 1

Achebe, Nwando, Samuel Adu-Gyamfi, Joe Alie, Hassoum Ceesay, Toby Green, Vincet Hiribarren, Ben KyeAmpadu(2018). History text book: West African Senior School Certificate examination. Available at: https://wasecehehistorytextbook.com/

Akinola, Adeoye(2018). 'The Role of International Financial Institutions in Africa', in Samuel O Oloruntoba and Toyin Falola. eds. The Palgrave handbook of African politics, governance and development. New York, NY : Palgrave Macmillan

Angele, Luis (2012). On the Causes of the African Slave. Workshop paper on Economic Growth presented at university of Cambridge for congress of the royal economic society.

Annan, N (2014). Violent Conflicts and Civil Strife in West Africa: Causes, Challenges and Prospects. Stability: International Journal of Security and Development, 3(1), p. Art. 3. DOI: http://doi.org/10.5334/sta.da

Benton, Adia, and Kim Yi Dionne (2015). 'International political economy and the 2014

West African Ebola outbreak'. African Studies Review. Volume 58 No. 1.

Hardy,W(2014). Rise and fall of slave trade, an article

M'Baye,Babacar (2006). The Economic, political, and social Impacts of the Atlantic Slave trade on Africa, the European Legacy, vol.11, No.6.

M'Bokolo,Elikia(1998). The impact of slave trade on Africa, an article

Mlambo, Alois. 2018. 'African Economic History and Historiography'. Oxford Research Encyclopaedia of African History. Oxford: Oxford University Press

Njomen, Nkwinja(2015). The economic impact of corruption in Africa and the way for ward, case study: Cameroon

Nunn, Nathan (2008). The long Term Effects of African's Slave Trades, Journal of Economics.

Nunn, Nathan (2006). The long Term Effects of African's Slave Trades. Article, Department of Economics, university of British Colombia and Canadian institute for advanced research

Whatley,Warren (2012). The transatlantic slave trade and the evolution of political authority in West Africa, MPRA paper No.44932

Zhang, $\mathrm{Yu}(2016)$. Impacts of slave trade on current conflict in sub-Saharan Africa, paper presented at 2016 agricultural and applied economics, Texas A and M university. 